\section{Maconha: qual a amplitude de seus} prejuízos?

\section{Cannabis: how far is it}

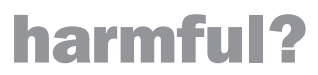

A maconha é a droga ilícita mais usada em todo o mundo. O uso da maconha geralmente é intermitente e limitado; no entanto, estima-se que $10 \%$ dos que experimentaram maconha tornam-se usuários diários e 20 a 30\% a consomem semanalmente. Dados da Austrália mostram que os indivíduos têm iniciado o uso bem mais cedo e a concentração de delta9-tetrahidrocanabinol (THC, principal substância psicoativa presente na maconha) está 30\% maior do que há 20 anos atrás. ${ }^{1-2}$ Alguns autores sugerem que damos menos atenção aos danos causados pela maconha por seus efeitos nocivos não serem tão óbvios como o de outras drogas. ${ }^{1}$ No entanto, nos últimos anos, começou-se a investir em pesquisas buscando avaliar a amplitude dos efeitos do uso desta droga. Este tema é particularmente importante para profissionais de saúde mental, pois os maiores prejuízos relacionados ao uso da maconha são os transtornos mentais que acabam sendo relacionados com o consumo.

Uma conferência internacional intitulada "Cannabis e Saúde Mental", em dezembro de 2004, no Instituto de Psiquiatria da Universidade de Londres, abordou dois aspectos opostos relacionados à maconha e saúde mental: 1) as conseqüências do uso recreacional, abuso e dependência da maconha; 2) o uso terapêutico dos derivados da maconha (canabinóides). Neste editorial, trataremos dos estudos relacionados ao impacto do uso de maconha. A partir de estudos com o THC, Mechoulam et al descobriram o sistema endocanabinóide humano. Receptores cerebrais (CB1) e neuromoduladores (ex: anandamida) têm um papel importante na fisiologia cerebral regulando diversos sistemas neurotransmissores, tais como: dopaminérgico, serotonérgico, colinérgico, glutamatérgico e gabaérgico. Estudos com animais mostram que o uso crônico de THC determina um desbalanço no sistema endocanabinóide e, por conseqüência, alterações nos diversos sistemas neurotransmissores.

A maconha é a droga ilícita mais usada por grávidas e estudos com animais e fetos humanos abortados evidenciam efeitos deletérios cerebrais devido à exposição intra-uterina à maconha que podem determinar alterações na vida adulta, inclusive na predisposição para o consumo da droga. ${ }^{3}$ Vários estudos mostram que a maconha pode produzir alterações cognitivas; usuários crônicos apresentam déficits em várias áreas, incluindo aprendizado verbal, memória de curto prazo, atenção e funções executivas. ${ }^{1-2} \mathrm{O}$ impacto cognitivo é maior quanto mais precoce e maior a duração do uso. Ainda não está claro se as alterações cognitivas melhoram com a abstinência prolongada e estudos maiores investigando a irreversibilidade dos déficits neuropsicológicos associados ao uso prolongado desta substância são necessários.

Uma série de estudos tem se concentrado num tema muito em voga atualmente, a relação entre uso de maconha e psi$\operatorname{cose}^{2,4}$ Verdoux et al estudaram populações de estudantes e 
constataram que a maconha é um fator de risco para experiências psicóticas na vida diária. Uma meta-análise realizada recentemente mostrou que a maconha duplica o risco de psicose e contribui para 8 a $13 \%$ dos casos de psicose na população. ${ }^{2}$ Mary Cannon et al analisaram dados de um estudo de coorte populacional realizado na Nova Zelândia² e mostraram que a maconha estava associada à emergência de psicose em uma minoria de usuários portadores de uma variação alélica do gene da enzima COMT (catechol-O-methyltransferase). Estes achados evidenciam a interação entre predisposição genética e a exposição ambiental à maconha no desenvolvimento dos quadros psiquiátricos, já que os indivíduos portadores de genes relacionados com a esquizofrenia têm uma chance muito maior de desenvolver a doença quando usam maconha do que os que não têm o gene.

A maconha determina alterações cerebrais mais sutis do que o álcool, cocaína ou heroína. 0 artigo de Crippa et al, ${ }^{5}$ neste fascículo, faz uma revisão dos principais achados em relação ao impacto do uso da maconha no cérebro, ou seja, os efeitos neurotóxicos residuais. Poucos estudos examinaram esta questão com metodologia adequada, mas os autores mostram como os avanços das técnicas de neuroimagem estrutural e funcional se prestam para investigação dos efeitos da maconha e seus derivados no cérebro. O artigo sugere novos caminhos para investigação de alterações cerebrais sutis, tais como estudos com desenhos adequados combinando diferentes técnicas de neroimagem e avaliações cognitivas.

Atualmente, está claro que a maconha é mais prejudicial quanto mais cedo se começa, quanto mais anos se usa e se houver exposição intra-uterina. A maconha não é condição necessária ou suficiente para a ocorrência de quadros psicóticos, mas é um componente causal que interage com outros componentes causais, tais como genótipo, condições ambientais e de neurodesenvolvimento. Apesar das alterações cerebrais relacionadas ao uso da maconha serem mais sutis que as alterações determinadas por outras drogas, não significa que elas não existam e não sejam relevantes. Com o avanço das técnicas exploratórias do cérebro humano vemos um caminho a seguir. Acreditamos que a combinação de diversas abordagens que permitam avaliar os indivíduos sob diferentes aspectos, tais como clínica, psicossocial, terapêutica, neuropsicológica, neuroimagem (estrutural, funcional e molecular) e genética, poderemos ter dados mais precisos sobre as conseqüências do uso da maconha.

A maconha sempre foi uma planta polêmica e continua sendo, pois além de ser uma droga de abuso que pode causar prejuízos, ${ }^{1-4}$ ela contém uma série de substâncias com propriedades terapêuticas comprovadas e potenciais. Informações científicas coerentes que favoreçam o esclarecimento destes dois aspectos diametralmente opostos da maconha podem facilitar imensamente as discussões sobre o uso da maconha e seus componentes na nossa sociedade.

Flavia S Jungerman e Ronaldo Laranjeira Uniad - Unidade de Pesquisa em Álcool e Drogas, Departamento de Psiquiatria, Universidade Federal de São Paulo (UNIFESP)

Rodrigo A Bressan

LiNC - Laboratório Interdisciplinar de Neuroimagem e Cognição, Departamento de Psiquiatria, Universidade Federal de São Paulo (UNIFESP)

\section{Referências}

1. Hall W, Solowij N. Adverse effects of cannabis. Lancet. 1998;352(9140):1611-6.

2. Castle DJ, Murray R. Marijuana and madness; psychiatry and neurobiology. Cambridge, UK: Cambridge University Press; 2004.

3. Smith AM, Fried PA, Hogan MJ, Cameron I. Effects of prenatal marijuana on response inhibition: an fMRI study of young adults. Neurotoxicol Teratol. 2004;26(4):533-42.

4. Witton J, Murray RM. Reefer madness revisited: cannabis and psychosis. Rev Bras Psiquiatr. 2004;26(1):2-3.

5. Crippa JA, Lacerda AL, Amaro E, Busatto G, Zuardi AW, Bressan RA. Brain effects of cannabis: neuroimaging findings. Rev Bras Psiquiatr. 2005;27(1):70-8 